\title{
A methodology to estimate the potential of grid-connected $P V$ residential systems for greenhouse gas emission reductions
}

\author{
A. Bermudez-Contreras, A. Ivanova-Boncheva \\ \& A. Martínez de la Torre \\ Department of Economics, \\ Universidad Autonoma de Baja California Sur, Mexico
}

\begin{abstract}
This paper presents a methodology to estimate the maximum greenhouse gas emission mitigation potential of grid-connected photovoltaic residential systems. To this aim, electricity generation in the national-grid-isolated state of Baja California Sur, Mexico, is studied and emissions factors calculated ( $\mathrm{kg} \mathrm{CO} 2 \mathrm{e} / \mathrm{kWh}$ ). In parallel, a simple approach based on peak sun hours is used to estimate the monthly electricity generation of grid-connected photovoltaic systems operating within the net metering scheme currently in use in Mexico. This investigation obtained an emissions factor of $0.892 \mathrm{~kg} \mathrm{CO}_{2} \mathrm{e}$ per $\mathrm{kWh}$ of electricity consumed in Baja California Sur and an annual electricity generation by a local photovoltaic system of $1825 \mathrm{kWh}$ per $\mathrm{kW}$ of installed nominal capacity. With these figures, the upper limit of the mitigation potential of grid-connected photovoltaic residential systems in the state is estimated at $577425 \mathrm{Mg} \mathrm{CO}_{2} \mathrm{e}$ per annum. The general methodology could also be applied to other zero-emissions renewable energy technologies in use elsewhere.
\end{abstract}

Keywords: emissions, GHG, BCS, Baja California Sur, methodology, Mexico.

\section{Introduction}

Baja California Sur (BCS) is a state in northwest Mexico. It is the least populated state in the country (almost 640,000 inhabitants; data for 2010) and it also has the lowest population density ( 9 inhabitants $/ \mathrm{km}^{2}$ ). Nevertheless, the state's population has been growing rapidly in recent years at rates considerably above the national 
average. During the past decade (2000-2010) BCS's population grew at $4 \%$ annually while the national average growth was only $1.4 \%$ [1].

Not surprisingly then, BCS had the highest growth rate of maximum electricity demand in Mexico during the past decade (2001-2010: 6.1\%) and this trend is expected to go on into the current decade (2011-2020: 6.4\%) and up to $2026(7 \%)$ [2]. Since BCS operates in isolation from the national electricity grid, this situation results in an urgency to build new power plants locally so as to keep up with the rising demand. Given the electricity generation technologies currently in place and those under construction or in planning $[2,3]$ the emissions of greenhouse gases (GHG) associated with electricity generation in BCS are also expected to increase in the coming years.

\section{Electricity generation and emissions factor in BCS}

Most energy needs around the world are fulfilled by burning fossil fuel $[4,5]$. One of the most important consequences of this is the release of GHG emissions (GHGE). By the end of 2010, the global concentration of $\mathrm{CO}_{2}$ emissions in the atmosphere had already passed the 390 ppm mark [6].

This situation also prevails in BCS. Here, road transport is driven by petrol and diesel, while LPG is used as a heat source for cooking. Likewise, electricity in BCS is generated in CFE's (the Federal Electricity Commission, is the stateowned, national power utility and sole electricity provider in Mexico).power plants mostly by burning diesel oil and a type of heavy residual fuel called "combustoleo", a residual fuel that comprises all heavy products including the vacuum residue, Virgin Stock, absorption residue and long residue (see the power plant inventory presented in Table 1). Consequently, power generation in BCS is undoubtedly contributing to the rising GHGE observed worldwide.

Fortunately, BCS has clean, renewable energy (RE) resources that can be used to generate electricity $[7,8]$. The use of RE to mitigate GHGE has been extensively studied around the world [9-16]. Furthermore, in addition to RE's GHGE mitigation potential, RE can also have wider impacts on national development including social, political and economic growth, enhancement of energy security, job creation and also the promotion of improvements in health, education and gender equality $[6,17]$. At present, about $2 \%$ of the electricity generated in BCS comes from geothermal energy. Besides, the recent addition of two solar photovoltaic (PV) plants (1 MW, government-owned; $30 \mathrm{MW}$, privately-owned) will further increase the contribution of renewables in the state, resulting in a larger amount of avoided GHG emissions.

To assess the carbon intensity of power generation in BCS (i.e., $\mathrm{kg}$ of GHG emissions per $\mathrm{kWh}$ ), the GHGE associated to electricity generation between years 2005 and 2010 were estimated according to the 1996 Intergovernmental Panel on Climate Change (IPCC) Guideline [20-22]. Subsequently, emission factors in $\mathrm{kg}$ of $\mathrm{CO}_{2}$ equivalent $\left(\mathrm{kg} \mathrm{CO}_{2} \mathrm{e}\right)$ per $\mathrm{kWh}$ of electricity consumed $\left(\mathrm{EF}_{\mathrm{c}}\right)$ were calculated. The emission factors obtained for the period range between 0.839 and $0.992 \mathrm{~kg} \mathrm{CO} 2 \mathrm{e} / \mathrm{kWh}$ with an average of $0.892 \mathrm{~kg} \mathrm{CO}_{2} \mathrm{e} / \mathrm{kWh}$ (as shown in Table 2). This value is about $50 \%$ higher than the Mexican national average of 
Table 1: CFE's power stations in BCS. (Source: authors' elaboration with data from $[18,19]$.

\begin{tabular}{|c|c|c|c|}
\hline $\begin{array}{c}\text { Power station } \\
\text { name }\end{array}$ & $\begin{array}{c}\text { Effective } \\
\text { capacity } \\
(\mathrm{MW})\end{array}$ & Type & Fuel \\
\hline Tres Vírgenes & 1 & Solar photovoltaics & Solar \\
\hline Tres Vírgenes & 10 & Geothermal & Geothermal \\
\hline Guerrero Negro & 0.6 & Wind & Wind \\
\hline $\begin{array}{c}\text { Ciudad } \\
\text { Constitución }\end{array}$ & 33 & Turbogas & Diesel oil \\
\hline La Paz & 43 & Turbogas & Diesel oil \\
\hline Los Cabos & 85 & Turbogas & Diesel oil \\
\hline $\begin{array}{l}\text { Guerrero Negro } \\
\text { (Mobile) }\end{array}$ & 2.9 & Turbogas & Diesel oil \\
\hline $\begin{array}{l}\text { Santa Rosalía } \\
\text { (Mobile) }\end{array}$ & 12.5 & Turbogas & Diesel oil \\
\hline $\begin{array}{c}\text { Cabo San Lucas } \\
\text { (Mobile) }\end{array}$ & 12.5 & Turbogas & Diesel oil \\
\hline $\begin{array}{c}\text { Cabo San Lucas } \\
\text { (Mobile) }\end{array}$ & 19 & Turbogas & Diesel oil \\
\hline $\begin{array}{c}\text { Cabo San Lucas } \\
\text { (Mobile) }\end{array}$ & 19 & Turbogas & Diesel oil \\
\hline $\begin{array}{c}\text { Baja California } \\
\text { Sur I }\end{array}$ & 121 & Internal combustion & $\begin{array}{c}\text { "Combustoleo"+ } \\
\text { Diesel oil }\end{array}$ \\
\hline $\begin{array}{l}\text { Gral. Agustín } \\
\text { Olachea A. }\end{array}$ & 104 & Internal combustion & $\begin{array}{c}\text { "Combustoleo"+ } \\
\text { Diesel oil }\end{array}$ \\
\hline $\begin{array}{c}\text { Guerrero Negro } \\
\text { II }\end{array}$ & 11 & Internal combustion & $\begin{array}{c}\text { "Combustoleo"+ } \\
\text { Diesel oil }\end{array}$ \\
\hline Santa Rosalía & 7 & Internal combustion & Diesel oil \\
\hline Punta Prieta II & 112.5 & $\begin{array}{c}\text { Thermal (steam } \\
\text { turbine) }\end{array}$ & $\begin{array}{c}\text { "Combustoleo"+ } \\
\text { Diesel oil }\end{array}$ \\
\hline TOTAL & 594 & & \\
\hline
\end{tabular}


$0.59 \mathrm{~kg} \mathrm{CO} 2 \mathrm{e} / \mathrm{kWh}$ for the same period (see national data for Mexico in [23]. This suggests that replacing the consumption of conventionally-generated electricity with renewable (clean) electricity would offset a larger volume of GHGE in BCS than in other parts of the country, i.e., the mitigation potential per $\mathrm{kWh}$ is larger in BCS. These emission factors indicate the maximum amount of emissions that could be displaced (avoided) if zero-emissions energy sources such as solar or wind energy were adopted to generate electricity. Therefore, the emission factors presented above can be used to estimate the GHG emissions mitigation potential of these technologies.

Table 2: Fuel consumption, GHGE, electricity sales and emission factors in BCS. Electricity sales data from [24] and fuel consumption data from [18].

\begin{tabular}{|c|c|c|c|c|c|}
\hline \multirow[b]{2}{*}{ Year } & \multicolumn{2}{|c|}{$\begin{array}{l}\text { Fuels used in electricity } \\
\text { generation }\end{array}$} & \multirow{2}{*}{$\begin{array}{c}\mathrm{GHG} \\
\text { emissions } \\
\left(\mathrm{Gg} \mathrm{CO}_{2} \text { eq }\right)\end{array}$} & \multirow{2}{*}{$\begin{array}{c}\text { Electricity } \\
\text { consumption } \\
\text { (sales) } \\
\text { (GWh) }\end{array}$} & \multirow{2}{*}{$\begin{array}{c}\text { Emissions } \\
\text { factor } \\
\left(\mathrm{kg} \mathrm{CO} \mathrm{CO}_{2} \text { eq }\right. \\
\text { per } \mathrm{kWh})\end{array}$} \\
\hline & $\begin{array}{l}\text { Diesel oil } \\
\qquad\left(\mathrm{m}^{3}\right)\end{array}$ & $\begin{array}{l}\text { Combustoleo } \\
\qquad\left(\mathrm{m}^{3}\right)\end{array}$ & & & \\
\hline 2005 & 87,000 & 348,000 & 1,228 & 1,315 & 0.934 \\
\hline 2006 & 194,000 & 327,000 & 1,437 & 1,448 & 0.992 \\
\hline 2007 & 98,000 & 372,000 & 1,323 & 1,578 & 0.839 \\
\hline 2008 & 122,000 & 420,000 & 1,525 & 1,770 & 0.862 \\
\hline 2009 & 122,000 & 426,000 & 1,543 & 1,806 & 0.855 \\
\hline 2010 & 122,000 & 433,000 & 1,562 & 1,808 & 0.864 \\
\hline & & & & Average & 0.892 \\
\hline
\end{tabular}

To enable an international comparison, an emissions factor in $\mathrm{kg}$ of $\mathrm{CO}_{2}$ per $\mathrm{kWh}$ of electricity generated $\left(\mathrm{EF}_{\mathrm{g}}\right)$ in $\mathrm{BCS}$ was also calculated. For 2010 , this

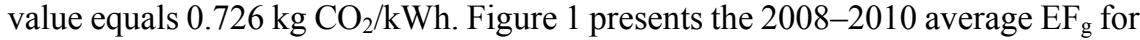
selected countries and regions reported by the International Energy Agency [25] and also includes the value calculated for BCS ( it must be noted that to enable the comparison with data presented by [25], the $\mathrm{EF}_{\mathrm{g}}$ considers only $\mathrm{CO}_{2}$ emissions and uses the total electricity generated. This is unlike the $\mathrm{EF}_{\mathrm{c}}$, which in addition to $\mathrm{CO}_{2}$ also includes $\mathrm{CH}_{4}$ and $\mathrm{N}_{2} \mathrm{O}$, and uses the electricity consumption/sales as reference). It can be seen that while the value for $\mathrm{BCS}$ is greater than the value for Mexico and other OECD countries, it is at the same time lower than the value for other regions of the world. 


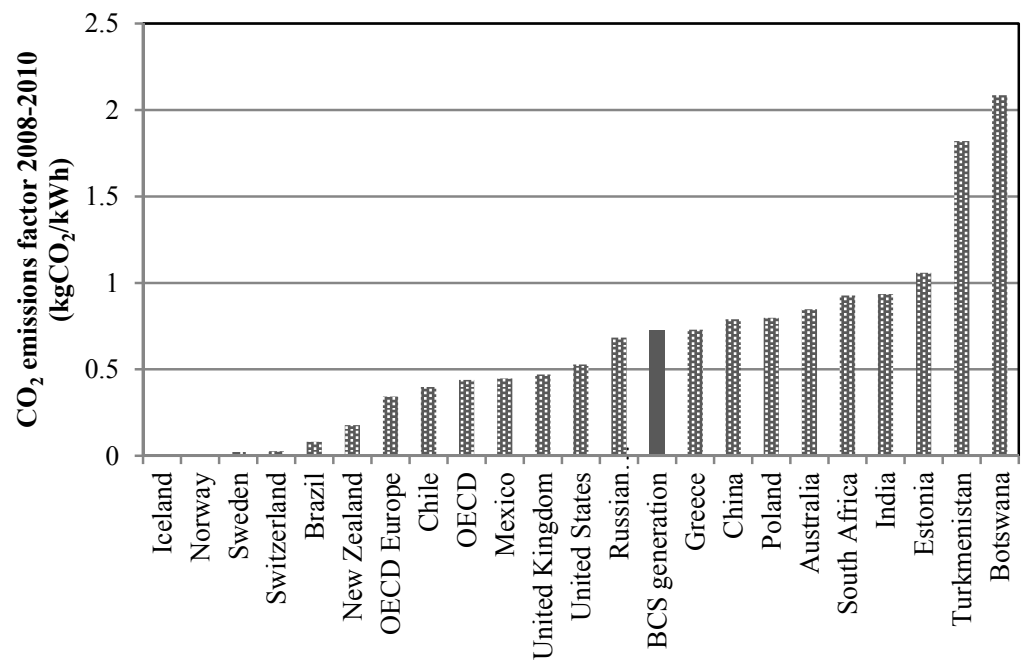

Figure 1: $\quad \mathrm{CO}_{2}$ emissions per $\mathrm{kWh}$ of electricity generated (selected countries/regions). (Source: authors' elaboration with some data from [25].)

\section{Solar energy in BCS}

Solar energy is an abundant resource in BCS. Throughout the state, average values range from $5.6-6.5 \mathrm{kWh} / \mathrm{m}^{2}$ with highs above $7 \mathrm{kWh} / \mathrm{m}^{2}$ in the summer months $[26,27]$. These values are amongst the highest in Mexico.

This has been evident for a long time and photovoltaic technology has been used in BCS to power remote applications like basic lighting, refrigeration, water pumping and desalination [7]. However, most of the electricity consumption in BCS takes place within CFE's electricity networks. Therefore, for PV systems to have a significant effect on GHGE, such systems must be grid-connected (GC) so as to offset some of the electricity generated in the local CFE power plants.

\section{Interconnection of small-scale grid connected systems in Mexico}

In Mexico, electricity supply is governed by the Electric Energy Public Service Law. After modifications in 1992, this law now allows electricity generation by private individuals under the categories of small production, self-supply, cogeneration and independent production. This modification was the first step towards grid-connection of privately-owned electricity generating systems based on renewable energy.

A further step was taken later on in 2001, when the first version of the model contract for grid-connection of small-scale renewable energy electricity systems was published by the energy regulator. This model contract was subsequently 
modified in the following years leading up to the current version which was published in 2010. This, together with the so-called "model contract for smallscale renewable energy collective source" and a new law for the exploitation of renewable energy in Mexico, the LAERFTE (Law for the Exploitation of Renewable Energies and Financing of the Energy Transition), approved in 2008 [28], make it possible to install small scale renewable energy systems (including solar PV) in private homes and businesses and interconnect them to the CFE grid. These contracts operate under a "net metering" scheme where individuals can export surplus electricity to the grid after meeting their own needs or take electricity from the grid during periods of shortfall. At the end of the billing period, an invoice is issued for the net difference between the two. In case of a net surplus of electricity exported to the grid during the billing period, this is recorded and can be used to offset total or partial consumption in future invoices (up to twelve months from the time of generation). It must be noted that, unlike schemes currently in place in other countries [17], under these contracts system owners are never paid any money for their generation, not even in the case of a surplus exported to the grid.

In Mexico, net metering has proved to be an efficient scheme to foster renewable energy generation on-site. With this framework, as of December 2012, there were 1640 small-scale grid-connected renewable energy systems registered in México and 60 medium-scale [29], with a combined capacity of $6147 \mathrm{~kW}$ and $6960 \mathrm{~kW}$, respectively. In the small-scale bracket, $99.5 \%$ of the total capacity corresponds to solar systems and the rest to wind systems. In the medium-scale bracket, solar accounts for $63 \%$ of the total capacity, biogas for $36 \%$ and biomass for the remaining $1 \%$. A total of 30 such systems (small and medium scale) are in BCS.

To estimate the GHGE reduction potential of grid-connected PV residential systems (GCPVRS), it is first required to determine how much conventional electricity could be offset by a GCPVRS. To this aim, two models were developed. The first estimates a user's monthly electricity consumption and the second estimates the monthly solar electricity produced by a given GCPVRS. These two models are explained in detail below.

\section{Electricity consumption model}

A model was developed to estimate the monthly electricity demand of users in different consumption bands. For this, a yearly profile that reflects seasonal and month-to-month variations was required. This was realised using local monthly residential electricity sales data for 2012 (Figure 2). The profile shows a marked increase in electricity consumption during the summer and early autumn months. This is the result of local temperature variation patterns which result in higher air conditioning loads during these months. The profile data were obtained directly from the local office of the power utility CFE. 


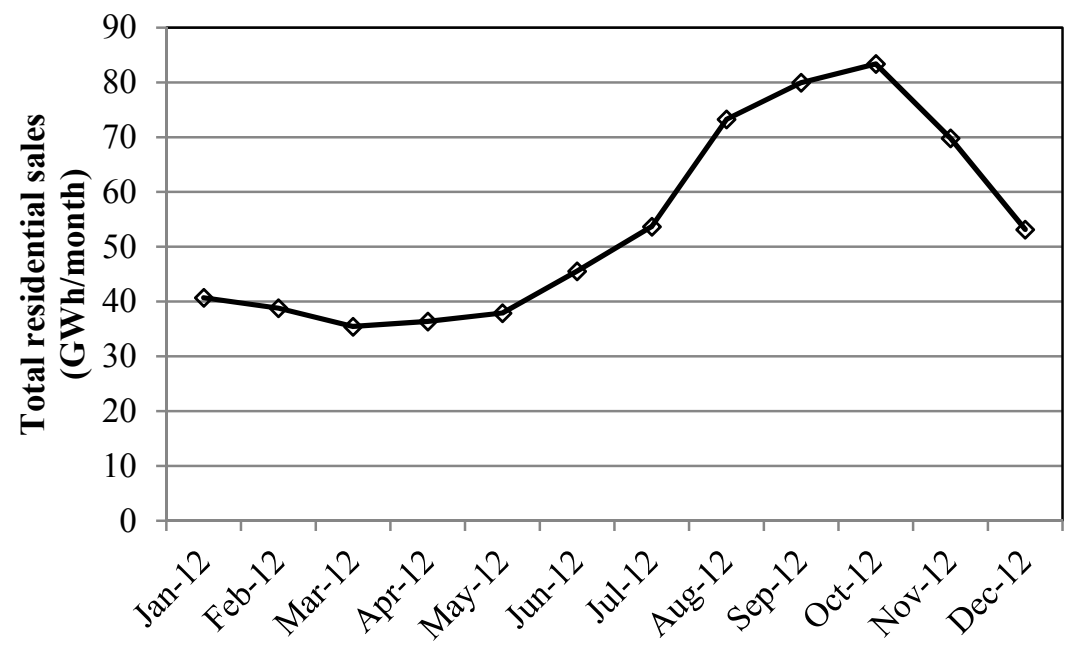

Figure 2: Total monthly sales in all residential tariffs in BCS during 2012. (Source: data provided by CFE.)

Subsequently, the total sales profile was normalised (see Figure 3 ) so that the yearly average of electricity sales during all months of the year equals one. The normalised profile can be used to estimate the monthly electricity demand for customers with different consumption levels by multiplying the normalised profile by a customer's average monthly consumption over a year.

\section{PV electricity generation model}

Once the electricity consumption profile of a user is known, it is then possible to design a GCPVRS that would generate enough electricity so as to supply the user's consumption over the whole year. An algorithm was developed and programmed into Matlab to size such a system. In the algorithm, the electricity production of the GCPVRS is computed for each month, and the cumulative sum is also calculated to obtain the yearly output of the system.

As the solar radiation and electricity demand profiles don't match perfectly, during some months the solar system will generate less electricity than the user needs while in others there'll be a surplus of electricity. Fortunately, the "net metering" scheme currently in use in Mexico allows surplus electricity from GCPVRS to be exported to the grid. This is recorded as an energy credit and can be used at a later date (up to 12 months later) to offset the user's grid electricity consumption during times with a net deficit, i.e., when the user draws more electricity from the grid than what is exported after meeting his own needs.

The algorithm used to size the GCPVRS and estimate monthly electricity generation is based on peak sun hours (PSH), i.e., the number of hours that the sun would have to shine at a constant power of $1000 \mathrm{~W} / \mathrm{m}^{2}$ on a horizontal surface that 
would result in the same amount of energy as that naturally received by the same surface in a given day. While the PSH approach used does not have the electricity generation prediction accuracy of more complex models that incorporate other variables (e.g., ambient temperature, wind speed, operating cell temperature), for the purpose of this research the PSH method used provides an acceptable balance of simplicity and accuracy.

The solar electricity generation profile obtained with this method (normalised) is presented in Figure 3. Since both profiles have the same year average (before and after normalisation), over the year, the total amount of electricity consumed by the user and that produced by the solar system are equal. Figure 5 illustrates that the GCPVRS users will export a net surplus of electricity to the grid between February and July, earning energy credits. These credits will be used during January and from August to December to cover their deficit.

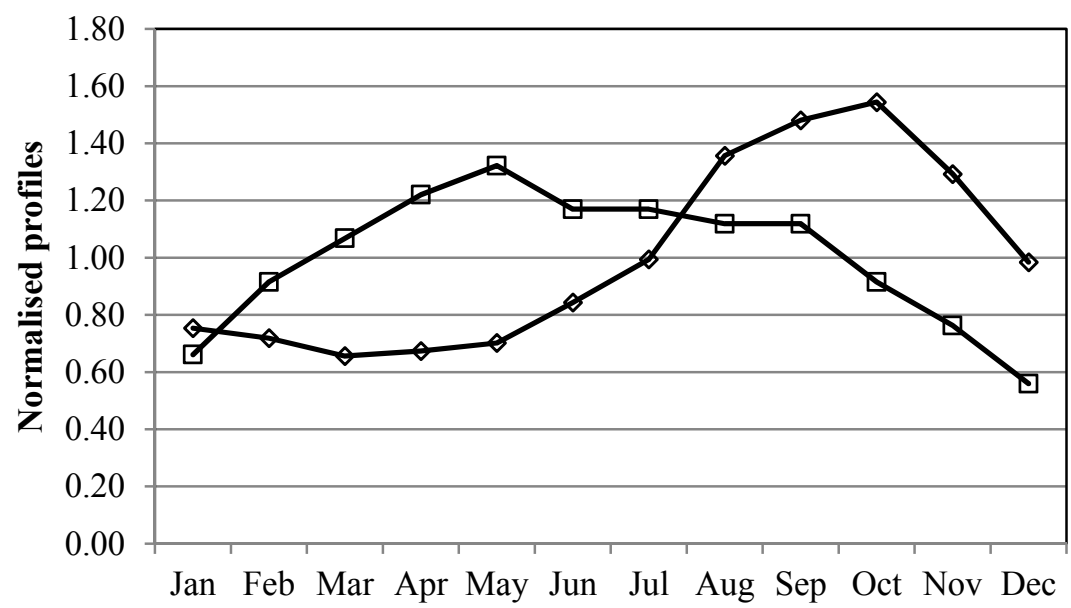

$\multimap$ Electricity consumption profile $\square$ Solar electricity generation profile

Figure 3: Profile comparison (normalised): solar electricity generation and electricity consumption.

\section{Maximum potential for emissions reduction using GCPVRS}

To estimate the maximum amount of GHGE that could avoided by the installation and use of GCPVRS in BCS, the emissions factor calculated above $\left(0.892 \mathrm{~kg} \mathrm{CO} \mathrm{CO}_{2} \mathrm{e} / \mathrm{kWh}\right)$ will be used. For this estimate it is also assumed that every $1 \mathrm{kWh}$ of electricity generated with a GCPVRS offsets $1 \mathrm{kWh}$ of electricity generated in the local power plants although the actual value will be different since the power utility will need to "backup" fluctuating generation, and also, electricity generation in situ for self-consumption by a GCPVRS also eliminates power losses associated with transmission and distribution.

With these considerations and the models described in previous sections, a GCPVRS with a capacity of $1 \mathrm{~kW}$ would save up to $1606 \mathrm{~kg} \mathrm{CO}_{2} \mathrm{e}$ per annum. 
This system would produce enough electricity over the year to cover the demand of a user with a monthly average consumption of $150 \mathrm{kWh}$ (with the considerations detailed in the section 6 above). Table 3 shows the theoretical maximum amount of GHGE that could be avoided by the installation of GCPVRS to reduce consumption of conventional electricity in BCS for consumers of different levels. While users could choose to install a GCPVRS to cover a smaller fraction of their electricity consumption, for the purpose of this study it is assumed that the PV systems installed totally offset consumption, as this represents the maximum GHGE reduction potential. Alternatively, the information presented in Table 3 could also be regarded as the amount of GHGE that users in various consumption levels are responsible for.

Table 3: $\quad$ Maximum avoided GHGE by the use of GCPVRS in BCS.

\begin{tabular}{|c|c|c|c|c|}
\hline \multirow{2}{*}{$\begin{array}{l}\text { Electricity } \\
\text { consumption }\end{array}$} & \multirow{2}{*}{$\begin{array}{c}\text { Electricity } \\
\text { consumption }\end{array}$} & \multicolumn{2}{|r|}{ GCPVRS } & \multirow{2}{*}{$\begin{array}{c}\text { GHGE } \\
\text { offset }\end{array}$} \\
\hline & & Power & Electricity generated & \\
\hline $\begin{array}{c}\text { (kWh per } \\
\text { month) }\end{array}$ & $\begin{array}{c}\text { (kWh per } \\
\text { year) }\end{array}$ & $(\mathrm{kW})$ & (kWh per year) & $\begin{array}{l}\left(\mathrm{kg} \mathrm{CO} \mathrm{CO}_{2} \mathrm{e}\right. \\
\text { per year })\end{array}$ \\
\hline 250 & 3,000 & 1.6 & 3,000 & 2,676 \\
\hline 500 & 6,000 & 3.3 & 6,000 & 5,352 \\
\hline 1,000 & 12,000 & 6.6 & 12,000 & 10,704 \\
\hline
\end{tabular}

Thus, in order to assess the potential for GHGE reduction in the whole state of BCS using GCPVRS, the total electricity consumption of residential users must be considered. These users are the second largest consumer of electricity in BCS with a total of $647,337 \mathrm{MWh}$ for the whole year during 2012. This consumption was distributed amongst 211,881 customers, equating to an average monthly consumption of $255 \mathrm{kWh}$ per customer over the year.

Finally, with this information and the emissions factor calculated above, the upper limit of the GHGE reduction potential using GCPVRS in BCS equates to $577,425 \mathrm{Mg} \mathrm{CO}$ e $(1 \mathrm{Mg}=1000 \mathrm{~kg}=1$ metric ton $)$. Using the PSH method detailed earlier, and assuming that every current customer installed a GCPVRS, such a volume of offset emissions would require the installation of GCPVRS with a combined power of $355 \mathrm{MW}(1.7 \mathrm{~kW} /$ installation on average).

\section{Conclusions}

Electricity generation in BCS is achieved almost entirely by burning heavy fuel oil (combustoleo) and diesel fuel resulting in a very high emissions factor of $0.892 \mathrm{~kg} \mathrm{CO}_{2} \mathrm{e}$ per $\mathrm{kWh}$ of electricity consumed in BCS, clearly above the national average. In addition, plans for future power plants in BCS consider only fossil fuels as their energy source. Solar energy, on the other hand, is abundant in BCS and is already used by a few residential consumers to generate electricity in grid- 
connected systems. The installation of more GCPVRS can help in reducing the total amount of electricity that the local power plants must generate and consequently and more importantly, also in reducing the volume of GHGE released into the atmosphere as well as the carbon intensity of local electricity generation.

With the methodology proposed, this work estimated an upper limit for GHGE reduction potential in BCS using GCPVRS of at 577,425 $\mathrm{Mg} \mathrm{CO}_{2} \mathrm{e}$ per year. The methodology uses monthly solar radiation data, an electricity consumption curve, the local emission factor and takes into account the current grid-connection policy (in the case of Mexico, net metering).

Finally, while solar photovoltaic residential systems and data for BCS were used to illustrate the development and application of the methodology proposed, the methodology is easily applicable to other zero-emissions renewable energy technologies in use elsewhere in the world and could also be extended to other sectors in addition to residential consumption.

\section{References}

[1] INEGI, Principales resultados del Censo de Población y Vivienda 2010, (2011). Available at: http://www.inegi.org.mx/sistemas/biblioteca/ detalle.aspx? $\mathrm{c}=28097 \& u p c=702825002042 \& \mathrm{~s}=\mathrm{est} \& \mathrm{tg}=320 \& \mathrm{f}=2 \& \mathrm{pf}=\mathrm{Pob}$ $\& \mathrm{ef}=00 \& \mathrm{cl}=0$.

[2] CFE, Programa de Obras e Inversiones del Sector Eléctrico 2012-2026, (2012). Available at: http://www.cfe.gob.mx/ConoceCFE/1_AcercadeCFE /Paginas/Publicaciones.aspx.

[3] CFE, Programa de Obras e Inversiones del Sector Eléctrico 2011-2025, (2011). Available at: http://www.energia.gob.mx/portal/Mobil.aspx?id $=1453$.

[4] IPCC, Climate Change 2007: Mitigation. Contribution of Working Group III to the Fourth Assessment Report of the Intergovernmental Panel on Climate Change, Cambridge University Press, Cambridge, UK and New York, NY, USA, Cambridge, 2007.

[5] IEA, Key World Energy Statistics, Paris, 2012.

[6] IPCC, IPCC Special Report on Renewable Energy Sources and Climate Change Mitigation, Cambridge University Press, Cambridge, UK and New York, NY, USA, Cambridge, 2011.

[7] Bermudez-Contreras, A., M. Thomson \& D.G. Infield, Renewable energy powered desalination in Baja California Sur, Mexico, Desalination. 220 (2008) 431-440. Available at: http://linkinghub.elsevier.com/retrieve /pii/S001191640700642X 10.1016/j.desal.2007.01.046.

[8] Bermudez Contreras, A.S. Energías renovables para la generación de electricidad en Baja California Sur, in: A. Ivanova, A.E. Gámez (Eds.), Baja California Sur Ante El Cambio Climático: Vulnerabilidad, Adaptación y Mitigación, UABCS, La Paz, 2013: pp. 384-415.

[9] Ghosh, D., P.R. Shukla, A. Garg \& P.V. Ramana, Renewable energy technologies for the Indian power sector: mitigation potential and 
operational strategies, Renewable and Sustainable Energy Reviews. 6 (2002) 481-512. Available at:

http://www.sciencedirect.com/science/article/pii/S1364032102000151 http://dx.doi.org/10.1016/S1364-0321(02)00015-1.

[10] Sims, R.E.H, H.-H. Rogner \& K. Gregory, Carbon emission and mitigation cost comparisons between fossil fuel, nuclear and renewable energy resources for electricity generation, Energy Policy. 31 (2003) 1315-1326. Available at:

http://www.sciencedirect.com/science/article/pii/S0301421502001921 http://dx.doi.org/10.1016/S0301-4215(02)00192-1.

[11] Winkler, H, A. Hughes \& M. Haw, Technology learning for renewable energy: Implications for South Africa's long-term mitigation scenarios, Energy Policy. 37 (2009) 4987-4996. Available at: http://www.sciencedirect.com/science/article/pii/S0301421509004790 http://dx.doi.org/10.1016/j.enpol.2009.06.062.

[12] Mathiesen, B.V., H. Lund \& K. Karlsson, 100\% Renewable energy systems, climate mitigation and economic growth, Applied Energy. 88 (2011) 488501. Available at: http://www.sciencedirect.com/science/article/pii/ S0306261910000644 http://dx.doi.org/10.1016/j.apenergy.2010.03.001.

[13] McHenry, M.P. A technical, economic, and greenhouse gas emission analysis of a homestead-scale grid-connected and stand-alone photovoltaic and diesel systems, against electricity network extension, Renewable Energy. 38 (2012) 126-135. Available at: http://linkinghub.elsevier.com /retrieve/pii/S0960148111004034 10.1016/j.renene.2011.07.020.

[14] Mahesh, A \& K.S. Shoba Jasmin, Role of renewable energy investment in India: An alternative to $\mathrm{CO} 2$ mitigation, Renewable and Sustainable Energy Reviews. 26 (2013) 414-424. Available at: http://linkinghub.elsevier.com /retrieve/pii/S1364032113003729 10.1016/j.rser.2013.05.069.

[15] Narbel, P.A. What is really behind the adoption of new renewable electricity generating technologies?, Energy for Sustainable Development. 17 (2013) 386-390. Available at: http://www.sciencedirect.com/science/article/pii /S0973082613000215 http://dx.doi.org/10.1016/j.esd.2013.03.002.

[16] Schmid, E., M. Pahle \& B. Knopf, Renewable electricity generation in Germany: A meta-analysis of mitigation scenarios, Energy Policy. 61 (2013) 1151-1163. Available at: http://www.sciencedirect.com/science/ article/pii/S0301421513006125 http://dx.doi.org/10.1016/j.enpol.2013.06.105.

[17] REN21, Renewables 2013 Global Status Report, REN21 Secretariat, Paris, 2013.

[18] Muhlia Melo, A. Inventario de emisiones de gases de efecto invernadero de BCS (2005-2010), La Paz, 2012.

[19] CFE, Centrales generadoras al mes de junio de 2013, (2013). Available at: http://www.cfe.gob.mx/ConoceCFE/1_AcercadeCFE/Estadisticas/Paginas/ Centrales-generadoras.aspx.

[20] IPCC, Revised 1996 guidelines for national greenhouse gas inventories Reporting instructions (volume 1), IPCC, 1997. 
[21] IPCC, Revised 1996 guidelines for national greenhouse gas inventories Workbook (volume 2), IPCC, 1997.

[22] IPCC, Revised 1996 guidelines for national greenhouse gas inventories Reference manual (volume 3), IPCC, 1997.

[23] SEMARNAT, INECC, México - Quinta comunicación nacional ante la Convención Marco de las Naciones Unidas sobre el Cambio Climático, SEMARNAT, Morelos, México, 2012.

[24] INEGI, Volumen de las ventas de energía eléctrica, (2011). Available at: http://www3.inegi.org.mx/sistemas/biinegi/default.aspx.

[25] IEA, $\mathrm{CO}_{2}$ emissions from fuel combustion highlights, International Energy Agency, 2012.

[26] Galindo Estrada, I. \& M. Valdés Barrón, México: Atlas de Radiación Solar, PUE - UNAM, 1991.

[27] SIGER, GENC, IIE, Mapa nacional de irradiación solar global, (2009).

[28] SENER, Decreto por el que se expide la Ley para el Aprovechamiento de Energías Renovables y el Financiamiento de la Transición Energética, in: Diario Oficial de La Federación 28 Noviembre 2008.

[29] CFE, Comportamiento de los contratos de interconexión en pequeña y mediana escala, (2013). Available at: http://www.cre.gob.mx/documento 12109.pdf. 